\title{
Can the PSI be Legitimate for the Nonproliferation Regime?A Critical Analysis
}

\author{
Eric Yong Joong Lee*
}

The Proliferation Security Initiative was launched in 2003 by the Bush administration right after the So San incident. Its primary purpose is to interdict the spread of WMD and their delivery systems. Due to the provocative and challenging characteristics of the Initiative, which are inconsistent with conventional international law, there are some objections against the Initiative. This paper answers the highly topical questions regarding the Initiative in three parts. The first part addresses the origin and development of the Initiative. The second part critically analyzes the background of the Initiative such as the neoconservative ideology of the Bush administration and its world strategy, international terrorism, and the U.S. arms industry. The third part scrutinizes questions concerning the preemptive use of force for self-defense and the interdiction of foreign vessels on the territorial and high seas. The Initiative is also examined from a viewpoint of customary international law.

\section{Keywords}

PSI, Interdiction, Freedom of the Sea, Preemptive Self-Defense, Customary International Law

\section{Introduction}

The Proliferation Security Initiative ("PSI") is a highly controversial issue in the postCold War era. As a newly established framework for nonproliferation of Weapons of Mass Destruction ("WMD"), the PSI has raised many challenging questions to the conventional principles of international law, including the legitimacy of interdiction on

* Professor of International Law at Dongguk University, Seoul, Korea; President of YIJUN Institute of International Law. B.A.(U.Washington), M.P.A.(Seoul Nat' l Univ.), LL.M.(Leiden), Dr.iur.(Erasmus). The facts and views reflected in this article are his own. The author may be contacted at: grotian@hotmail.com/Address: 56 Migaro, Kwangjin-gu \#302, Seoul 143-825 Korea. 
the high seas. This paper will try to answer these questions from a viewpoint of international law.

This paper is composed of three parts. Part II will be review the origin and evolution of the PSI. As a worldwide network designed to prevent the spread of WMD, the PSI was declared by U.S. President George W. Bush in 2003 just after the September 11 attack and the following So San incident. The PSI is a new world strategy, which began in the US under neoconservative wing of the Bush administration, and comports with the "national strategy combating terrorism." The PSI was the framework for how the Bush administration intended to govern the post-Cold War world. Based on these understandings, a few basic questions regarding the functioning and operation of the PSI will be discussed. Part III will cover some of the underpinnings of the PSI, including the U.S. neoconservative strategy international terrorism and the world's arms industry. Part IV will analyze the legal issues relating to the PSI, including a close analysis of Article 51 of the UN Charter and review the examples of the preemptive use of force for self-defense, interdiction of foreign vessels on the high seas from the perspective of the law of the sea, and whether the PSI is a customary international norm.

\section{Formation}

\section{Genesis of the PSI}

The September 11 attacks drastically changed the world. Nearly 3,000 people were killed and wounded in this horrible act of terrorism, which was presumably committed by Al Qaida. Following the attacks, the U.S. invaded Afghanistan in order to capture Osama bin Laden, the leader of the radical Islamist militant group who was believed to be behind the attacks and residing in Afghanistan. However, the invasion was not successful although the Taliban religious faction of Afghanistan was disposed of its ruling power. The "war against terrorism" was neither efficient nor effective in protecting global stability due to the fundamental difference between the current war against terrorism and those fought during the Cold War era, namely that the enemy has become more indiscernible and ubiquitous. Today, terrorists are not necessarily statesponsored, but rather come from non-State actors ("NSAs"). The United States respond to this new reality accordingly. The Bush administration released the "national strategy combating terrorism" 1 as a top national security priority in December 2002, which called

1 The U.S. Department of States, National Strategy to Combat Weapons of Mass Destruction, available at http://www.state.gov/documents/organization/16092.pdf (last visited on Apr. 5, 2010). 
for enhanced interdiction capabilities. ${ }^{2}$

Another incident soon followed. The So San, a Cambodian-registered North Korean freight, was interdicted in the Indian Ocean about 960 kilometers from its destination in Yemen. The So San flew no flag and loaded fifteen Scud missiles underneath 40,000 sacks of cement. ${ }^{3}$ Although the So San was initially seized, it was later released because international law did not prohibit Yemen from accepting delivery of the missiles from North Korea. 4 Pursuant to the United Nations Convention on the Law of the Sea ("UNCLOS"), vessels may be stopped only by their flag state. ${ }^{5}$ In the case of a non-flag vessel like the So San any country can stop and inspect the ship. However, the cargo aboard the ship is a different matter because transporting weapons at sea does not violate international law unless the transporting state has a treaty to refuse such weapons. Because Yemen and North Korea were neither party to the Missile Technology Control Regime, ${ }^{6}$ nor at war with Spain or the U.S., the vessel could not be detained or its cargo seized.7 This embarrassing incident spread a great concern to policymakers in the U.S. They were particularly worried that WMD could fall into the hands of rogue states or NSAs who are willing to use WMD to undermine global security. 8 Therefore, U.S. policymakers finally decided to develop the PSI, a worldwide network for the interdiction of WMD.

\section{Development of the PSI}

\section{A. Structure of the PSI}

The PSI aims to stop shipments of biological, chemical nuclear weapons as well as missiles and goods that could be used to deliver or produce such weapons to terrorists

2 J. Ashley Roach, Proliferation Security Initiative (PSI): Countering Proliferation by Sea: paper presented to conference in Xiamen, China 1-2 (March 2005).

3 Frederic L. Kirgis, Boarding of North Korean Vessel on the High Seas, ASIL InsIGHTS (Dec. 2002), available at http://www.asil.org/insights/Insigh94.htm (last visited on Mar. 26, 2010).

4 James Harding et al., US Releases Missiles Ship for Yemen, Financial Times 10 (London) (Dec. 12, 2002). For details on the So San incident, see also, D. Guilfoyle, The Proliferation Security Initiative: Interdicting Vessles in International Waters to Prevent the Spread of Weapons of Mass Destruction?, 23 MeLbouRne U. L. Rev. (2005); Daniel Joyner, The Proliferation Security Initiative: Nonproliferation, Counterproliferation, and International Law, 30 YALE J. INT'L L. 508 (2005).

5 UNCLOS, art. 92; 1833 U.N.T.S. 3.

6 GuIdelines For SENSitive Missile Relevant Transfer, available at http://www.mtcr.info/english/guidetext.htm (last visited on Mar. 27, 2010).

7 Kirgis, supra note 3. See also Samuel Logan, The Proliferation Security Initiative: Navigating the Legal Challenges, 14 J. TRans. L. \& PoL’Y 253-254 (2005).

8 U.S. Dept of State, Office of the Press Secretary, Proliferation Security Initiative: Statement of Interdiction Principles, available at http://www.state.gov/t/isn/c27726.htm (last visited on Mar. 27, 2010). 
and countries suspected of trying to acquire WMD. 9 The PSI was launched by U.S. President George Bush on May 31, 2003, in Krakow, Poland. In his speech, President Bush proposed a cooperative framework to coordinate national actions supporting interdiction as follows: 10

The greatest threat to peace is the spread of nuclear, chemical and biological weapons. We must work together to stop proliferation. ... When weapons of mass destruction or their components are in transit, we must have the means and authority to seize them. So today I announce a new effort to fight proliferation called the Proliferation Security Initiative. The U.S. and a number of our close allies, including Poland, have begun working on new agreements to search planes and ships carrying suspect cargo and to seize illegal weapons or missile technologies. Over time, we will extend this partnership as broadly as possible to keep the world's most destructive weapons away from our shores and out of the hands of our common enemies.

The PSI began as "a loose alliance of countries to non-proliferation of WMD via shipping routes on land, air and sea." 11 On September 4, 2003, these core member nations issued a non-binding "Statement of Interdiction Principles," which called for the use of diplomatic information and military instruments of power. 12 The preamble of the Principles states that "the participants are committed to establish a more coordinated and effective basis through which to impede and stop shipments of WMD, delivery systems, and related materials flowing to and from states and non-state actors of proliferation concern." 13 In addition, the PSI participants call on all states concerned with the threat to international peace and security to be committed to the following:14

1. Undertake effective measures for interdicting the transfer or transport of WMD;

2. Adopt streamlined procedures for rapid exchange of relevant information concerning suspected proliferation activity;

3. Review and work to strengthen their relevant national legal authorities where necessary to accomplish these objectives; and

4. Take specific actions in support of interdiction efforts regarding cargoes of WMD, their delivery systems, or related materials.

Peter Crail, The Proliferation Security Initiative At a Glance, available at http://www.armscontrol.org (last visited on Mar. 29, 2010).

10 Remarks by the President to the People of Poland, Wawel Royal Castle, Krakow, Poland, May 31, 2003, available at http://georgewbush-whitehouse.archives.gov/news/releases/2003/05/20030531-3.html (last visited on Apr. 5, 2010).

11 Logan, supra note 7, at 255.

12 Supra note 8.

13 Id.

14 Id. 


\section{B. How the PSI Operates?}

A main objective of the PSI is to prevent the spread of WMD among states and non-state actors of proliferation concern. States actors of concern include North Korea, Iran and Syria, while NSAs refer to various terrorist organizations around the world. 15 Currently, 95 countries are participating in or supporting the PSI as a counter-proliferation mechanism. The PSI works in three parts. First, it increases intelligence sharing between participating states. Second, it promotes operational cooperation among participating states to prepare and plan to interdict vessels transporting WMD.16 Operational detail will only be available upon specific instances of interdictions. 17 Third, it promulgates interdiction principles that permit participants to use force if necessary to halt the flow of WMD,18 which is "the most clearly articulated and contentious contribution" of the PSI.19

\section{Underpinnings What Brought the United States to Set Up the Interdiction Network?}

\section{The Neoconservatives}

The PSI has been designed by the U.S. neoconservatives 20 as a post-Cold War strategy 21 The Cold War completely ended by the early 1990s. However, this triumph was not welcomed news for the neocons of the Bush administration because as the traditional Cold War system abruptly collapsed and ideological confrontation between the East and West was over, former allies of the United States were less willing to continue to accept U.S. political and military dominance. To make matters worse, the U.S. economy began to slow at the turn of the 21st century. From the neocon perspective, this was a big paradigm-shift that they had never experienced in the latter half of the 20th century.

15 Logan, supra note 7, at 255-256.

16 Mark Shulman, The Proliferation Security Initiative and the Evolution of the Law on the Use of Force, 28 Hous. J. INT'L L. 795 (2006).

17 Id. at 796.

18 Id.

19 Id. at 797.

20 For details on the American neoconservatism, see Len Colodny \& Tom Shachtman, The ForTy Years WaR: The Rise AND FALL OF THE NEOCONS, FROM NIXON TO OBAMA (2009).

21 The idea of the PSI was specifically developed by John R. Bolton, former US Under-Secretary of State for Arms Control and International Security and former US Ambassador to the United Nations, after 15 Scud missiles found on board a North Korean freighter had to be released when it turned out that international law did not allow them to be confiscated. 
Therefore, the neocons urgently devise a new world strategy in order to maintain their position at the top of both domestic and international politics.

\section{International Terrorism}

The PSI was triggered by newly emerging acts of international terrorism. The September 11 attacks were a catalyst that exacerbated fear about the invisible terrorists and future attacks using WMD. As the panic from the September 11 attacks was fast dominating national psyche, the Neocons began designing a new network led by the U.S. military against international terrorism. The neocons maintained the following: that future terrorism would be more fatal and larger than people have experienced throughout history; that the terrorists are totally invisible and brutal; and that no one can easily prevent future attacks without a preemptive interdiction system because the terrorists do not belong to states but rather exist as secret terrorist groups under their unshakable Islamic solidarity. The neocons concluded that if these non-Christian terrorists commit attacks with WMD and highly sophisticated delivery systems the world would suffer unimaginable damage.22 Based on this, President Bush finally proposed the PSI as an indispensable measure to prevent future terrorist attacks.

\section{Shifting Strategy: From Deterrence to Preemption}

As a "worldwide web of interdiction" for nonproliferation of WMD, the PSI signifies the fundamental change to the U.S. world strategy "from deterrence to preemption." Deterrence was the basic military strategy of the US during the Cold War. It is "a strategy by which governments threaten an immense retaliation if attacked, such that aggressors are deterred if they do not wish to suffer great damage as a result of an aggressive action." 23 Deterrents include WMD, conventional weapon strength, economic sanctions, or any combination thereof. Therefore, "Mutually Assured Destruction" 24 was the key to understanding the deterrence during the Cold War: the United States and the former Soviet Union, although both preparing for a nuclear or

22 See The Nature of Terrorist Threat Today, available at http://georgewbush-whitehouse.archives.gov/news/releases/ 2003/02/counter_terrorism/threat.pdf (last visited on Apr. 5, 2010).

23 D. Yost, Analysing International Nuclear Order, 83 International AfFairs 549-574 (2007). For details on the deterrence theory, see also Morgan, Patrick, Deterrence Now (2003); LaWrence Freedman, Deterrence (2004); Complex Deterrence: Strategy in the Global Age (T.V. Paul, Patrick Morgan \& James Wirtz eds. 2009); Kenneth N.Waltz, Nuclear Myths and Political Realities, 84 Am. PoL. SCI. Rev. $731-745$ (1990); RoBert Jervis, Richard N. Lebow \& Janice G. Stein, The Psychology of DeterRence 270 (1985).

24 Alan J. Parrington, Mutually Assured Destruction Revisited, Strategic Doctrine in Question, 11 AIRPOWER JouRNAL (1997), available at http://www.airpower.maxwell.af.mil/airchronicles/apj/apj97/win97/parrin.html (last visited on Apr. 7, 2010). 
conventional war, were not willing to take the risk of a full scale nuclear war which would lead to the total destruction. 25 This recognition led to a balance of power between the United States and the Soviet Union. Although the deterrence strategy became more aggressive during the Reagan administration, it remained essentially a defensive military strategy.

However, as the Cold War ended, the United States reassessed its global policy based on the doctrine of the "war against terrorism." The Bush administration declared the "preemptive strike" against potential terrorist attacks as its basic policy. In other words, the United States will attack foreign regimes posing a potential or perceived threat to the security of the United States, even when that threat is not imminent. ${ }^{26}$ In his address to the U.S. Military Academy (West Point) on June 1, 2002, President Bush clarified the role of preemptive war in the future of American foreign policy and national defense. He said as follows: 27

We cannot defend America and our friends by hoping for the best. We cannot put our faith in the word of tyrants, who solemnly sign non-proliferation treaties, and then systemically break them. If we wait for threats to fully materialize, we will have waited too long.... Our security will require transforming the military you will lead - a military that must be ready to strike at a moment's notice in any dark corner of the world. And our security will require all Americans to be forward-looking and resolute, to be ready for preemptive action when necessary to defend our liberty and to defend our lives.

His remarks stressed that the United States had the right to secure itself against countries that harbor or give aid to terrorist groups.28 This proposal has been fully reflected in the PSI by allowing its member states to stop and inspect any suspicious ship even on the high seas in order to prevent the spread of WMD and their delivery systems.

25 Yost, supra note 23.

26 Mike Allen, Edwards Rejects the 'War on Terror,' TIME, May 2, 2007; Mark Levin, First Things First, NAT' L REV., Aug. 16, 2006; Susan Page, Confronting Iraq, USA TodAY EDUc., Mar. 17, 2003, available at http://www.usatoday.com/educate/iraq/war7-article.htm (last visited on Apr. 11, 2010).

27 U.S. Military Academy Press Release, President Bush Delivers Graduation Speech at the U.S. Military Academy in West Point (June 1, 2001), available at http://georgewbush-whitehouse.archives.gov/news/releases/2002/06/print/ 20020601-3.html (last visited on Apr. 3, 2010).

28 Steven R. Weisman, Editorial Observer; President Bush and the Middle East Axis of Ambiguity, N.Y. TimEs, Apr. 13, 2002, available at http://www. nytimes.com/2002/04/13/opinion/editorial-observer-president-bush-and-the-middle-eastaxis-of-ambiguity.html (last visited on Apr. 7, 2010). 


\section{U.S. Domination in the Global Arms Market}

The U.S. arms industry of the post-Cold War era is another lens through which one can view the PSI. The arms industry is a global business that manufactures and trades weapons and military technology and equipment. ${ }^{29}$ The arms industry has been very influential on the domestic and international politics of the United States, as former U.S. President Dwight D. Eisenhower famously described as a "military-industrial complex." 30 Right after the dissolution of the Soviet Union, global arms exports initially declined to half of the levels in the 1980s. However, since 2003 this market has grown to near the Cold War levels. Global military expenditures in 2008 are estimated to have totalled \$1.464 trillion. This figure represents a 4 percent increase in real terms compared to 2007, and a 45 percent increase since 1999. In 2008, military expenditures comprised approximately 2.4 percent of global gross domestic product ("GDP").31 The combined arms sales of the top 100 largest arms manufacturers amounted to an estimated $\$ 315$ billion in 2006.32 In 2004 over $\$ 30$ billion were spent in the international arms trade. 33 (Table 1 )

Table 1: World Military Expenditure 1988-2008

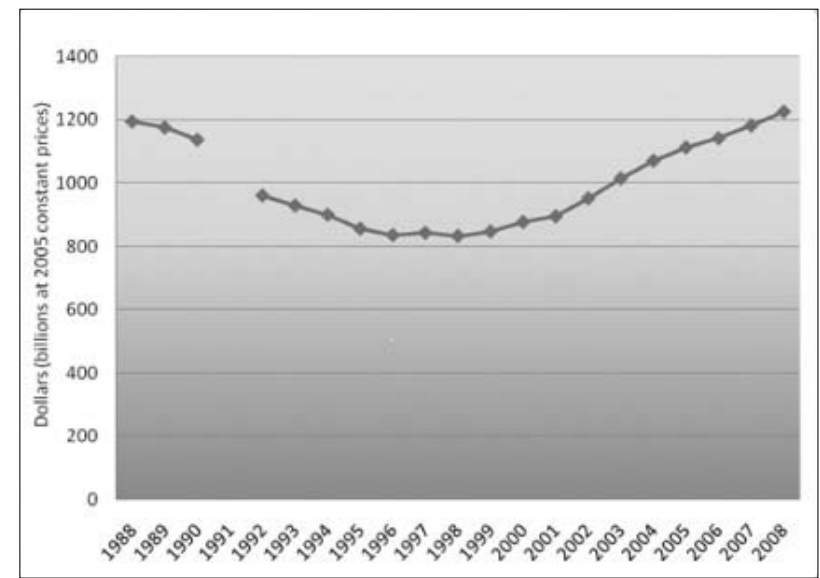

Source: Stockholm International Peace Research Institute Yearbook 2009 http://www.globalissues.org/article/75/world-military-spending

30 For details, see Dwight D. Eisenhower, The Military-Industrial Complex: Farewell AdDress to the Nation of JANUARY 17, 1961 (2006).

31 Sam Perlo-Freeman, Catalina Perdomo, Elisabeth Skons \& Petter Stalenheim, Military Expenditure, 2009 SIPRI Y.B. Ch.5 (2009). 
Particularly during the presidency of George W. Bush, U.S. military expenditures escalated to their highest levels since World War II. As a result, the United States has been the largest supplier of weapons to the developing world, accounting for approximately 36 percent of worldwide weapons sales. ${ }^{34}$ Not surprisingly, the fast increase of defense expenditures was initiated by the neocon wing of the Bush administration, many of whose members were closely interlinked with the U.S. arms industry. There is no doubt that the neocons wanted to dominate the world's arms trade. The So San ship was seized while transporting missiles, high value-added arms, but released because there was no international legal measure to prohibit the missile transaction. For the neocons, this constituted a 'black market.' The Bush administration began to find a legitimate mechanism to interdict the weapon trade between third world states.

\section{Legal Controversies}

\section{Preemptive Use of Force for Self-Defense}

Self-defense is a means for the members of any legal systems "to protect themselves by force if necessary against certain serious violations of their rights." 35 It is an inherent right recognized by customary international law. 36 The conditions for exercising selfdefense are laid down in Article 51 of the UN Charter, which provides: "[N]othing in the present Charter shall impair the inherent right to individual or collective selfdefense if an armed attack occurs against a member of the United Nations.” The phrase, "if an armed attack occurs" may literally imply that the armed attack must have already occurred before force can be used in self-defense. 37 Therefore, pursuant to Article 51 of the Charter, self-defense is permissible to the preservation or restoration of the status quo prior to the armed attack. Additionally, the means employed in the exercise of selfdefense have to be "necessary and proportional" to the violation that gave rise to the right to self-defense. 38

34 Thom Shanker, U.S. leads arms sales to developing countries, N.Y. TimEs (Sept. 30, 2007).

35 Brun-Otto Bryde, Self-Defense, 4 Encyclopedia of Public International LaW 212 (R. Bernhardt ED., 1982).

36 Christopher Greenwood, International Law and the Pre-emptive Use of Force: Afghanistan, Al-Qaida, and Iraq, 4 SAN DIEGo INT' L L. J. 11 (2003).

37 Peter MaLancZuk, Modern Introduction to International LaW 311(1997).

38 Bryde, supra note 35, at 213-214. On the traditional requirements of proportionality and necessity for self-defense, the ICJ, in the Nicaragua case, stated that: "there is a specific rule whereby self-defense would warrant only measure which is proportional to the armed attack and necessary to respond to it, a rule well established in international law." Military and Paramilitary Activities (Nicar. v. U.S.), 1986 I.C.J. 94, para. 176 (June 27). For details, Malanczuk, supra note 37 , at 317 . 
While Article 51 of the Charter does not allow preventive action in principle, there could be a situation in which a preemptive use of force against imminent attack is justified as self-defense. 39 With respect to the PSI, it is more controversial because interdiction is a kind of preemptive action. The classic formulation of the right to preemptive self-defense was established by the U.S. Secretary of State Daniel Webster in connection with the Caroline incident. In 1837 British troops attacked and sank an American ship, the Caroline in U.S. waters because the ship was being used to provide supplies to insurrectionists against British rule in Canada. The United States immediately protested this "extraordinary outrage" and demanded an apology and reparations. In the course of the diplomatic exchanges Secretary of State Daniel Webster articulated the two conditions essential to the legitimacy of the preemptive use of force under customary international law. 40 In one note, Secretary Webster asserted that an intrusion into the territory of another State can be justified as self-defense only when the necessity of that self-defense is instant, overwhelming, and leaving no choice of means and no moment for deliberation. ${ }^{41}$ In the other note, he also asserted that the force used in such circumstances has to be proportional to the threat. 42

In the era of the United Nations, a few cases were referred to as striking examples of preemptive self-defense. The first case was the Cuban Missile Crisis. In 1962, former U.S. President John F. Kennedy imposed a naval quarantine on Cuba in order to interdict the delivery of offensive weapons and associated materials. 43 At that time, however, the United States did not invoke the right to preemptive self-defense in order to justify the quarantine imposed on Cuba. The United States realized that such an attitude would create a precedent which the Soviet Union could have used against U.S. missile sites in Europe.44 The second case is the so-called Six-Day War of 1967 when Israel launched a preemptive attack on Egypt and other Arab states. Israel claimed the attack was defensive in nature and necessary to forestall an Arab invasion. The Security Council, however, adopted Resolution 242 calling on Israel to withdraw from the territories and for the termination of all claims or states of belligerency.45 The third case

39 Id. at 213.

40 D.M. Ackerman, International Law and the Preemptive Use of Force against Iraq, CRS REPORT FOR CoNGRESS (RS21314) 2 (2003).

41 Letter from Secretary of State Daniel Webster to Lord Ashburton of August 6, 1842, set forth in Moore, John Bassett, 2 A Digest of INTERNATIONAL LAW 412 (1906), recited in Ackerman, supra note 40.

42 Letter from Mr. Webster to Mr. Fox of April 24, 1841, 29 BRITISH AND FoREIGN STATE PAPERS 1129, 1138 (1857), recited in Ackerman, supra note 40.

43 Proclamation 3504, 27 Fed. Reg. 1004 (Oct. 25, 1962), recited in Ackerman, supra note 40, n. 13. For details on the Cuban Missile Crisis and preemptive self-defense, see R. Grimmett, U.S. Use of Preemptive Military Force, in CRS REPORT FOR CONGRESS (RS21311) 5-6 (2003).

44 Malanczuk, supra note 37 , at 312 .

45 S/RES/242 (Nov. 22, 1967). 
happened when Israel bombed and destroyed a nuclear reactor under construction in Iraq on June 7, 1981. Israel claimed that it only exercised its legitimate right to selfdefense within the meaning of international law in order to remove a terrible nuclear threat. 46 However, the Security Council passed Resolution 487 condemning the military attack by Israel as a clear violation of the Charter and the norms of international conduct. The Security Council also urged the payment of appropriate redress. 47 Considering the surroundings, the military attack was definitely an action beyond the right to self-defense. By the same logic promulgate by Israel, every state would claim to be threatened by a build-up of arms in a neighboring state and could resort to preventive war. 48 Another case was the United States bombing of Libya in response to a Libyan terrorist attack against U.S. soldiers in West Berlin in April 1986.49 In that case, the United States tried to justify the bombing as a preemptive action. (Table 2)

Table 2: The Preemptive Self-Defense Cases during the Cold War

\begin{tabular}{|l|l|l|l|}
\hline Year & Claimant & \multicolumn{1}{|c|}{ Situation } & \multicolumn{1}{c|}{ Result } \\
\hline 1962 & U.S. & $\begin{array}{l}\text { U.S. President John F. Kennedy } \\
\text { imposed a naval quarantine on Cuba } \\
\text { in order to interdict the delivery of } \\
\text { offensive weapons and associate } \\
\text { materials. }\end{array}$ & $\begin{array}{l}\text { U.S. did not invoke the right to } \\
\text { preemptive self-defense in order to } \\
\text { justify the quarantine imposed on } \\
\text { Cuba. }\end{array}$ \\
\hline 1967 & Israel & $\begin{array}{l}\text { Israel launched a preemptive attack } \\
\text { on Egypt and other Arab states. }\end{array}$ & $\begin{array}{l}\text { The Security Council, however, } \\
\text { adopted Resolution 241 calling on } \\
\text { Israel to withdraw from the territories } \\
\text { and for the termination of all claims } \\
\text { or states of belligerency. }\end{array}$ \\
\hline 1981 & Israel & $\begin{array}{l}\text { Israel bombed and destroyed a } \\
\text { nuclear reactor under construction } \\
\text { in Iraq. }\end{array}$ & $\begin{array}{l}\text { TheSecurity Council passed Resolution } \\
\text { 487 condemning the military attack } \\
\text { by Israel in clear violation of the } \\
\text { Charter and the norms of international } \\
\text { conduct and urged the payment of } \\
\text { appropriate redress. }\end{array}$ \\
\hline 1986 & U.S. & $\begin{array}{l}\text { U.S. bombing of Libya, in response } \\
\text { to a Libyan terrorist attack against } \\
\text { the U.S. soldiers in West Berlin. }\end{array}$ & $\begin{array}{l}\text { The bombing was criticized by non- } \\
\text { aligned countries as "an unprovoked } \\
\text { act of aggression." }\end{array}$ \\
\hline
\end{tabular}

\footnotetext{
4620 I.L.M. 996 (July 1981).

47 S/RES/487 (June 19, 1981).

48 Malanczuk, supra note 37 , at 312.

49 Id. at 316.
} 
In the post-Cold War era, the Iraq War of 2003 used to be referred to as preemptive self-defense. U.S. President Bush launched the military action against Iraq on March 19, 2003. Just before the Iraq War the Bush administration, by way of the "National Security Strategy of the United States of America," clearly stated that: "[T]he United States is prepared to use preemptive military force to prevent enemies from using WMD against it or its allies and friends." 50 President Bush did not, however, explicitly characterize this military action as an implementation of the expansive concept of preemptive use of military force against WMD. 51 Whether this military action was a preemptive strike against the imminent threat of Iraq is arguable, considering the traditional concept of preemptive use of force. 52

Under current international law, disputes between states should be resolved by peaceful means. The use of force is illegal except in two cases: Security Council authorization and self-defense. As mentioned earlier, the conditions for self-defense are provided in Article 51 of the UN Charter. Article 51 of the Charter was drafted in order to outlaw a war and use of force as a means of national policy.53 The article reflects a dream of all mankind to prevent indiscreet use of force. If generally permitted the preemptive use of force would allow every country to invoke the same reason for defending its military action against other countries. Therefore, the preemptive use of force for self-defense should be justified only when an armed attack is imminently threatening the territorial integrity and political independence of a state. 54

\section{Interdiction vs. Freedom of the Sea}

\section{A. Freedom of Navigation}

The freedom of navigation on the high seas has been a fundamental principle of modern international law. It has been historically recognized by the international community since the 17th century. Hugo Grotius, in his masterpiece Mare Liberum, wrote that: "[T]he sea is an element common to all, because it is so vast that no one could possibly take possession of it. It is therefore fitted for use by all." 55 The principle of the freedom

50 National Security Strategy of the United States. of America (2002), available at http://www.globalsecurity.org/ military/library/policy/national/nss-020920.pdf (last visited on Apr. 7, 2010).

51 Grimmett, supra note 43 , at 6.

52 Id. For the traditional concept of preemptive use of force and its renovation, see Lee Jaemin, Terrorism Prevention and the Right of Preemptive Self-Defense, 1 J. EAST ASIA \& INT' L L.(“JEAIL”) 303 (2008).

53 Bryde, supra note 35 , at 213.

54 UN Charter, art. 2(4). For the similar opinions, see Greenwood, supra note 36, at 15. See also R. HigGins, Problems and Process: International LaW AND How We Use IT 242 (1994).

55 For English translation of Mare Liberim, see L.E. van HolK \& C.G. ROELOFSEN (EDS.), GROTIUS READER 59ff (1983), reprint of RalPh van Deman Magoffin, The Freedom of the SEAS, translated with a revision of the Latin Text of 1633 (1916). 
of navigation has been reconfirmed in Article 87 of the United Nations Convention on the Law of the Sea ("UNCLOS"). 56 This freedom has been of paramount importance with respect to freedom of the sea. 57

However, the freedom of navigation on the high seas could be limited under international law. It should be exercised with regard to "the interests of other States in their exercise of freedom of the high seas." 58 Every vessel must fly the flag; 59 and the flag State should effectively exercise its jurisdiction and control in administrative, technical and social matters over ships flying its flag. 60

In addition, the freedom of navigation principle faced another limitation from the PSI which allows member States to interdict suspicious ships on the high seas. Shortly after the launching of the PSI, North Korea described it as "a brigandish naval blockade akin to terrorism in the sea and a gross violation of international law." 61 In the current international community, all of whose members are standing equally under international law, it is not appropriate to assume the PSI's interdiction as legitimate. In order to gain legitimacy, the PSI "must be grounded in international law." 62 International law may have two positions regarding interdiction: territorial sea and the high seas.

\section{B. Interdiction in the Territorial Sea}

In the territorial sea, a coastal state's sovereignty extends seaward twelve nautical miles from its baseline.63 In this maritime area, costal states enjoy "law enforcement rights identical to those that it exercises on land within its boarder." 64 Here, ships may enjoy the rights to 'innocent passage.' 65 Article 19 of UNCLOS defines the innocent passage as the "navigation which is not prejudicial to the peace, good order or security of the costal State . . in conformity with this Convention and with other rules of international

56 UN Doc.A/CONF.62/122 with Corr.3 and Corr.8; UNCLOS III, Official records, Vol. XVII 151-221(1984); 1833 U.N.T.S. 3, reprinted in 21 I.L.M. 1261-1354 (1982). For details on the preservation of the non-interference principle in the UNCLOS, see Michael A. Becker, The Shifting Public Order of the Oceans: Freedom of Navigation and the Interdiction of Ships at Sea, 46 HARv. INT'L L. J. 172, Table 3 (2005).

57 UNCLOS, art. 87(1).

58 Id. art. 87(2); The Convention on the High Seas ("HSC"), art. 2.

59 UNCLOS, art. 92.

60 Id. art. 94. For details, see D.H.N. Johnson, Freedom of Navigation, in Bernhardt, supra note 35 (Vol. 11) 234 (1989).

61 Shulman, supra note 16 , at 804 .

62 Id. at 806.

63 UNCLOS, art. 3.

64 J.A. Doolin, The Proliferation Security Initiative: Cornerstone of a New International Norm, 59 NAVAL WAR CoLLEGE REv. 35 (2006).

65 Francesco Francioni, Peacetime Use of Force, Military Activities, and the New Law of the Sea, 18 CoRNELL INT'L L. J. 204-205 (1985). 
law." 66 In other words, a foreign ship's passage shall not be considered innocent when it engages in any threat or use of force against the sovereignty, territorial integrity or political independence of the coastal state, prejudicial to the defense or security of the coastal state, or in any other manner in violation of the principles of international law embodied in the UN Charter.67 For instance, a government may search and seize a vessel found within its own territorial sea subject to (1) a reasonable claim that such vessel's transit is prejudicial to the peace, good order or security of the coastal state; or to (2) any domestic law constraints, such as criminal procedure, due process, unlawful searches, and takings. 68 If a ship is navigating the territorial sea of foreign state with WMD and its delivery system on board, that passage would not be innocent. Therefore, the coastal state could stop the ship and inspect the cargo on board when the ship is suspected of carrying WMD. In such a case, the coastal state could curtail the right to innocent passage and force the ship to navigate out of its territorial sea. The coastal state's right to interdict the suspicious ship may be extended, if necessary, to the contiguous zone, another 12 nautical miles out of the territorial sea where the State is permitted to exercise its customs, fiscal, immigration, and sanitary laws. 69 The PSI interdictions would be legitimate under these limited circumstances.

A few more questions may arise, however, even in such a situation. The first question is whether a warship of State A could interdict a vessel of State B enjoying the innocent passage in the territorial sea of State C. If State A and the coastal State B are the members of the PSI and the coastal state permits the interdiction in advance, then it would be possible to interdict the vessel of State B in the territorial sea. Even in this case, however, the vessel of State B should be fully suspected of transporting WMD. Another question is what if the interdicted vessel is loading only delivery system(s) without WMD. In that case, they are not subject to seize because international law does not prohibit from transporting missiles which are not directly involved in WMD.

\section{Interdiction on the High Seas}

The PSI interdiction on the high seas is a totally different matter from that in the territorial sea. The high seas are open to all states under international law. 70 States, whether coastal or not, have the right to enjoy the freedom of the high seas with the "due regard" for the interests of other States.71 Only a flag state has the jurisdiction over

66 UNCLOS, art. 19(1)

67 Id. art. 19(2). For details, see Samuel Logan, The Proliferation Security Initiative: Navigating the Legal Challenge, 14 J. Transnat' L L. \& Pol'y 259 (2005).

68 Shulman, supra note 16 , at 807.

69 UNCLOS, art. 33.

70 Id. art. 87(1); HSC, art. 2.

71 UNCLOS, art. 87(2). 
its ship. If a state unlawfully and intentionally seizes or exercises control over another state's ship by force or threat thereof or any other form of intimidation, that will consist of an offence. 72 However, there are some exceptions to the flag state jurisdiction on the high sea such as: piracy (HSC, art. 14; UNCLOS, art. 100), unauthorized broadcasting (UNCLOS, art. 109), slave trading (HSC, art. 22; UNCLOS, art. 110), drug trafficking (UNCLOS art. 108), uncertain nationality (HSC, art. 22; UNCLOS, art. 110), stateless ship (HSC, art. 6(2); UNCLOS, art. 92), hot pursuit (HSC, art. 23; UNCLOS, art. 111) and major pollution (UNCLOS, art. 221).

Apart from these exceptions, states have sometimes justified interference with foreign ships on the high seas on the ground of self-defense or necessity. ${ }^{73}$ A classic incident is the Virginius case of 1873.74 During the emergency of 1956-62, France also asserted a right to visit and search on the high seas ships suspected of carrying arms to Algeria. The above-mentioned Cuban quarantine of 1962 is another example of interference with foreign shipping on the high seas. ${ }^{75}$ Another exception of flag state jurisdiction is "rights under special treaties." 76 The Northwest Atlantic Fisheries Organization ("NAFO") grants right to visit and search a ship in order to determine the ship's nationality.77 The United Kingdom and the United States concluded an agreement in 1981 to facilitate the interdiction by the United States, in defined areas of the Caribbean and Gulf of Mexico and up to 150 miles off the eastern seaboard of the United States, of British-flag vessels suspected of trafficking in drugs. In addition, Article 17 of the Vienna Convention against Illicit Traffic in Narcotic Drugs and Psychotropic Substances of 1988 provides that state parties may request each other's help in the repression of illicit traffic. In such ways, a sate party may request permission to board a vessel exercising freedom of navigation of another State party. ${ }^{78}$ The right "under special treaty," however, could not be invoked to interdict foreign vessels in the high seas because the PSI is not a treaty. Also, unlike these cases where the maritime areas or the destination states were concretely defined, the PSI interdiction is too general and ambiguous to invoke the right of self-defense or necessity on the high seas.

72 Convention for the Suppression of Unlawful Acts of Violence against the Safety of Maritime Navigation ("SUA Convention"), art. 3(1).

73 R.R. ChuRchill \& A.V. Lowe, The LaW of the SEA 216 (1999).

74 Jonathan Ault, The Virginius Incident, available at http://www.spanamwar.com/virginius.htm (last visited on Apr. 5, 2010).

75 Churchill \& Lowe, supra note 73 , at 216-217.

76 Id. at 218.

77 NAFO Convention, art. 18. It reads: "[T]his scheme shall include provision for reciprocal rights of boarding and inspection by the Contracting Parties and for flag State prosecution and sanctions on the basis of evidence resulting from such boardings and inspections..."

78 Id. at 218-219. 


\section{An Emerging Customary Norm?}

The PSI now has 95 participating and supporting states. They cover nearly a half of the UN member states including most of the major countries in the northern hemisphere. Based on this numeric power and the consensus of those countries, the United States has maintained that the PSI interdiction on the high seas should be recognized as a new customary international norm.79 The United States contends that without the limits of traditional principle for the preemptive self-defense, "imminence and necessity," the doctrine of self-defense could be used to justify virtually any use of force in the most volatile international contexts. 80

Customary international law has been the most fundamental source of international law for centuries although the codification of international law has been making considerable progress in many fields for the last few decades.81 Customary international law is created by what states do in practice, not created by what states put down in writing. 82 State practice and the opinio juris are the two elements of customary international law. State practice is formed by the "constant repetition of general practice of States" concerning a particular international question. A practice should be general although not universal to reflect wide acceptance among states particularly involved in the relevant activity. 83 Diplomatic immunity is a noticeable example on this point. Centuries ago, states began the practice of granting diplomats immunity from local jurisdiction for various practical reasons. As times passed, more states began to grant immunity until virtually all states were granting diplomatic immunity. Gradually, these states came to believe that granting such immunity was required by law. At this point, this "uniformity of practice" became customary international law. 84 Together, state practice should be supported by the opinion juris which can be defined as the "conviction that the State practice reflects binding legal obligations." 85 Lastly, customary international law used to be proved by evidences such as published materials, writings of international lawyers or judgments of national and international tribunals. 86

Doolin, supra note 64 , at 37-38, 48-50.

Jack I. Garvey, The International Institutional Imperative for Countering the Spread of Weapons of Mass Destruction: Assessing the Proliferation Security Initiative, 10 J. Conflict \& SECURITY L. 134 (2005).

Malanczuk, supra note 37, at 35; R. Bernhardt, Customary International Law, Bernhardt, supra note 35 (Vol. 7) at 61 (1984).

Anthony C. Arend, International Law and the Preemptive Use of Military Force, 26:2 THE WASHINGTON QUARTERLY 90 (Spring 2003).

Malanczuk, supra note 37 , at 42.

Arend, supra note 82.

Bernhardt, supra note 35, at 62 . Professor Peter Malanczuk similarly defines it as a "conviction felt by States that a certain form of conduct is required by international law." See Malanczuk supra note 37, at 44 .

Id. at 39 . 
Considering the above-mentioned conditions, the PSI should not be considered customary international law for the following reasons. First, the interdiction can not be accepted as a "constant and uniform usage," although 95 countries are directly and indirectly involved in this initiative. They took just dozens of joint interdiction exercises for the past number of years. Second, the PSI is not characterized as a treaty, but only as a collection of interdiction partnership. 87 Nor does the PSI have any substantial organization. A non-treaty network cannot be customary international law. Third, the PSI's basic document, "Interdiction Principle for the Proliferation Security Initiative" is a kind of joint declaration that lacks binding force between member states. A joint declaration is not a treaty, but a soft law. Fourth, Security Council Resolution 1540 confirmed just a basic position of the United Nations against the proliferation of WMD.88 Fifth, the opinion juris has not imposed yet on this incomplete practice. Finally, there is no room to consider instant customary law because the PSI is not formulated by multilateral treaties as is often the case with the former instant customary laws. ${ }^{89}$ As a consequence, if there is an interdiction of foreign vessels on the high seas without the consent of the flag State, that will be a violation of the principle of the freedom of navigation under international law. Furthermore, such interdiction is not likely to become customary international law in the foreseeable future. 90

\section{Conclusion}

This article has addressed questions regarding the legitimacy of the PSI interdiction under current international law of the sea. The PSI is critical to understanding the U.S. world strategy in the post-Cold War period. Designed by the neoconservative policymakers in the Bush administration as a loose nexus to interdict WMD, the PSI has raised many legal controversies inconsistent with the conventional principles of international law. The most critical issue is whether the PSI may be legitimate under UNCLOS which prohibits the interdiction of foreign vessels on the high seas without the consent of the flag state. Moreover, Article 51 of the Charter does not authorize a state to use its force preemptively unless the threat is imminent, although some scholars maintain that Security Council Resolution 1540 would be a ground for its

\footnotetext{
87 Bureau of Nonproliferation, US Department of State, Proliferation Security Initiative Frequently Asked Questions, Jan. 11 2005, available at http://www.state.gov/t/np/rls/fs/32725.htm (last visited on Mar. 30, 2010).

88 S/RES/1540 (Apr. 28, 2004). See Joyner, supra note 4, at 539-541.

89 Malanczuk, supra note 37 , at 45-46.

90 Mark J. Valencia, Is the PSI Really the Cornerstone of a New International Norm?, 59 NAVAL WAR C. REv. 127-128 (2006).
} 
legality. ${ }^{91}$ Resolution 1540 is insufficient in itself because it is no more than a confirmation of the basic position of the United Nations against the proliferation of WMD. 92

The high seas are open to all the people and their activities except for some cases against the peremptory norms such as piracy. Even limited military exercises on the high seas are admitted up to a reasonable level. Customary international law permits States to carry out naval maneuvers or conventional weapons testing on the high seas. 93 A vivid example is the French nuclear test carried out in the South Pacific without any legal objection. The International Court of Justice held that "French announcements of a termination of atmospheric testing had effectively brought an end to the dispute." 94 Therefore, under contemporary international law of the sea, interdiction of foreign vessels on the high seas would not be legitimate unless the navigation is imminently threatening the global peace and stability.

The author fully agrees that WMD is a fatal threat to the peace and security of the international community. All WMD should be completely abrogated on the earth. In that sense, the PSI would be an efficient tool for the nonproliferation of WMD. However, the main problem is its legitimacy. The core nations of the PSI, including the United States, should abide by current international law with respect to their double standards regarding nuclear policy. The United States, the biggest nuclear power in the world, has not even made any significant efforts for the nonproliferation of its own WMD. Furthermore, the United States withdrew from the Anti-Ballistic Missile ("AMB") Treaty in 2001 and has not yet ratified the Comprehensive Nuclear Test Ban Treaty ("CTBT"). President Obama's "Nuclear Posture Review" of April 6, 2010, only declared the "Negative Security Assurance" implying the conditional reduction of nuclear weapons. 95 The United States should keep in mind that it is still the world's largest WMD possessor. Fortunately, the United States and Russia signed the new Strategic Arms Reduction Treaty ("START") on April 8, 2010 by which the two nations will be limited to 1550 deployed strategic warheads. However, this is not enough just to realize the "world without nuclear arms." 96 Rather, the PSI could be used to share information and facilitate the communication among participating states against the flsheets/negsec (last visited on Apr. 15, 2010).

96 http://www.armscontrol.org/act/2010_05/Pifer (last visited on Apr. 5, 2010). 
proliferation of WMD. As nuclear powers fundamentally abrogate their WMDs, the PSI could play a fundamental role in the future as a general international legal instrument for supporting the nonproliferation regime of the world. 
